ISSN 1392-3196 / e-ISSN 2335-8947

Zemdirbyste-Agriculture, vol. 102, No. 2 (2015), p. 223-228

DOI $10.13080 /$ z-a.2015.102.029

\title{
Effect of drying methods on the chemical composition and colour of peppermint (Mentha $\times$ piperita L.) leaves
}

\author{
Marina RUBINSKIENE, Pranas VIŠKELIS, Edita DAMBRAUSKIENÉ, \\ Jonas VIŠKELIS, Rasa KARKLELIENĖ \\ Institute of Horticulture, Lithuanian Research Centre for Agriculture and Forestry \\ Kauno 30, Babtai, Kaunas distr., Lithuania \\ E-mail: m.rubinskiene@1sdi.lt
}

\begin{abstract}
The study was done with the two peppermint (Mentha $\times$ piperita L.) cultivars - 'Krasnodarskaja' and 'Peppermint', whose leaves were dried using different methods. Investigation of fresh and dried herbs was carried out according to the biochemistry and technology methods. Essential oil was extracted using the hydro distillation method, the amount of chlorophyll $a$ and $b$ was measured spectrophotometrically according to the Vernon method. The highest content of essential oil $(0.77 \%)$ and chlorophyll (1.69\%) was found in the cv. 'Peppermint'. Chlorophyll $a$ to $b$ ratio was different in the fresh peppermint leaves: in the cv. 'Peppermint' it was 1.35 and in the cv. 'Krasnodarskaja' - 1.44. Peppermint leaves were dried using active ventilation, convection, infrared, vacuum, microwave, and sublimation methods. The quality of dried herbs depended on the properties of plants and drying techniques. The highest content of essential oil (0.64-0.68\% of dry mass) was found in the variously dried peppermint leaves of the cv. 'Krasnodarskaja'. The lowest content of essential oil $(0.08 \%$ and $0.065 \%$ of dry mass) was determined in microwave dried herbs. The highest content of chlorophyll was found in the lyophilized peppermint leaves (715.0 $\mathrm{mg} 100 \mathrm{~g}^{-1}$ of dry mass) of the cv. 'Peppermint'. Regardless of the drying method, significant differences between the ratio of chlorophyll $a$ to $b$ were observed in the dried herbs of the cv. 'Krasnodarskaja'. The fresh and dried peppermint samples of the cv. 'Peppermint' had the lowest brightness L* value (from 22.61 to 35.24) and the lowest yellowness $b^{*}$ values (from 9.35 to 17.00). The biggest changes in greenness a* value were in microwave dried peppermint leaves.
\end{abstract}

Key words: chlorophyll $a$, chlorophyll $b$, drying methods, essential oil, Mentha $\times$ piperita.

\section{Introduction}

Aromatic plants are becoming increasingly popular with consumers. Apart from the flavouring use, people are also interested in medicinal and antiinflammatory properties (Risch, 1997). In the market, most herbs and spices are provided dried, because, due to the high water content in the fresh state, they undergo severe deterioration after microbial growth and biochemical reactions. Drying is one of the most antique processes to preserve quality of aromatic and medicinal plants. It consists of water removal from the raw material up to a level at which microbial spoilage and deterioration reactions are highly minimized (Rocha et al., 2011). Many researches on the mathematical modelling and experimental studies have been conducted on the drying processes of various products, such as mint (Mentha viridis L.) (Kouhila et al., 2001), aromatic and medicinal plants (Kavak Akpinar, 2006). Among the drying methods, the hot air drying is the most used method, but it can lead to thermal damage and can severely alter the volatile composition of herbs as well as the colour (Antal et al., 2011). Ambient temperatures and temperatures below $50^{\circ} \mathrm{C}$ are the best to retain volatile compounds
(Rocha et al., 2011). However, as determined, in hot air drying the loss of phenolic compounds and antioxidant activity reached up to $60 \%$ compared to freeze drying. The evaluation of other drying methods that remove moisture content at low temperatures with the use of irradiation or vacuum stands a challenging prospective (Harbourne et al., 2009; Orphanides et al., 2013). In recent years, microwave drying has been widely used as an alternative drying method for a wide variety of herbs and spices, and its effect on the quality of the dried product has been evaluated. Several food products have been successfully dried by microwave, hot air application and/or by combined microwave-convective drying (Shaw et al., 2007; Karaaslan et al., 2013).

The changes in biologically active constituents depend not only on drying process, but can be attributed to the specific compound and species (Stanisavljevic et al., 2012). The results showed that drying method had a significant effect on oil content and composition of aromatic plants. The literature indicates that most of the essential oil components decline at temperatures over $30^{\circ} \mathrm{C}$ (Yadegari et al., 2013). 
Mint plants are one of the most interesting research plants; they are between medicinal and aromatic plants (Mekonnen, 2011). Peppermint oil is one of the most important essential oils; it is used in pharmaceuticals, cosmetics and flavouring all over the world (Edris et al., 2003). The mint and its tea extract are rich in the essential minerals such as $\mathrm{Na}, \mathrm{Mg}, \mathrm{K}, \mathrm{Ca}, \mathrm{Cr}, \mathrm{Fe}, \mathrm{Co}$, $\mathrm{Cu}, \mathrm{Zn}$ and Se (Padmini et al., 2010). The spearmint oil has a potent antimicrobial activity. Previous studies have shown antibacterial, antifungal (Sulieman et al., 2011) and antioxidant activities (Kizil et al., 2010) of the water, ethanol and methanol herbal extracts.

The objectives of this study were to determine the effect of drying methods on biochemical compounds and changes in physical properties in dried peppermint.

\section{Materials and methods}

The object of this investigation was peppermint plants of cvs. 'Krasnodarskaja' and 'Peppermint'. Analyses were performed at the Institute of Horticulture, Lithuanian Research Centre for Agriculture and Forestry in 2012-2013.

Drying methods. Uncrushed peppermint leaves were dried using natural, convection, infrared, vacuum, microwave and sublimation drying methods: 1) active ventilation (A) drying was performed at a temperature of $22 \pm 2{ }^{\circ} \mathrm{C}$ and an air-flow rate of $1.5 \mathrm{~m} \mathrm{~s}^{-1} ; 2$ ) convective (C) drying was performed in a UDS-150/1 hot-air laboratory dryer ("Utenos krosnys", Lithuania) at a temperature of $39 \pm 1{ }^{\circ} \mathrm{C}$ and an air-flow rate of $1.5 \mathrm{~m} \mathrm{~s}^{-1} ; 3$ ) infrared (I) drying was performed with a moisture analyser HA310 IR (Precisa Gravimertics AG, Switzerland) at $39 \pm 1{ }^{\circ} \mathrm{C}$, wavelength range $1.2-6.0 \mu \mathrm{m}$; 4) microwave/ high-frequency electromagnetic waves $(\mathrm{M})$ drying was performed in a microwave oven AFMW290 (AFTRON, Korea) at a frequency of $2450 \mathrm{MHz}$ and an intermediate power of $500 \mathrm{~W}$; 5) sublimation/lyophilisation (S) was performed in a sublimator $3 \times 4 \times 5$ (ZIRBUS Technology $\mathrm{GmbH}$, Germany), the condenser temperature was $-85^{\circ} \mathrm{C}$, and the vacuum was $2 \times 10^{-6} \mathrm{mPa}$, the samples were frozen at $-40^{\circ} \mathrm{C}$ in a laboratory freezer, and then left in the freeze drier for 96 hours; 6) vacuum (V) drying was performed at $30 \pm 1.0^{\circ} \mathrm{C}$ and a pressure of $7 \times 10^{-6} \mathrm{mPa}$ in a dryer FD8512S (ilShin ${ }^{\circledR}$ Europe, The Netherlands). The experiments of drying methods were carried out in triplicate. The sample size was one kilogram of fresh peppermint leaves.

Investigations of green (fresh mass, f.m.) and dried (dry mass, d.m.) herbs were carried out according to the methods applied at the Laboratory of Biochemistry and Technology, Institute of Horticulture, Lithuanian Research Centre for Agriculture and Forestry. Ascorbic acid was measured by titration with 2,6-dichlorphenolindophenol sodium chloride solution (AOAC, 1990 a); soluble solids - by a digital refractometer ATAGO PR-32 (ATAGO Co. Ltd., Japan). Monosaccharides and sucrose content in berries were determined by the Bertrand method (AOAC, 1990 b). For determination of dry mass, leaves were dried in a drying oven at $105^{\circ} \mathrm{C}$ for $24 \mathrm{~h}$. The amount of nitrates was measured potentiometrically, with an ionselective electrode. The essential oil from the plant was extracted by hydro distillation method using a Clevenger type apparatus (AOAC, $1990 \mathrm{c}$ ). Essential oil content of the fresh or dried peppermint leaves was calculated by the formula:

$\mathrm{x}=\alpha \times 100 / \mathrm{m}$, where $\mathrm{x}$ is the essential oil content, percent $\mathrm{v} / \mathrm{w}, \alpha$ - essential oil content, $\mathrm{ml}, \mathrm{m}-$ fresh or dried leaves content, g.

Content of chlorophyll $a$ and $b$ was measured spectrophotometrically according to the Vernon (1960) method by a double-array spectrophotometer, model Genesys 10 UV (Thermospectronic, USA).

Chlorophyll $a$ and $b$ measurement in dried peppermint leaves. Dry chopped material $(0.5 \mathrm{~g})$ of a sample was transferred to a $50 \mathrm{ml}$ conical-necked Erlenmeyer flask. The flask was filled with $20 \mathrm{ml} \mathrm{80 \%}$ acetone and sealed with a silicone stopper. Chlorophyll extraction was carried out in a water bath at a temperature of $30^{\circ} \mathrm{C}$ for 30 minutes. Then the content of the flask was transferred to a porcelain mortar, which was then ground with a small amount of $80 \%$ acetone and $\mathrm{MgCO}_{3}$. The solution was filtered through a glass filter through a vacuum pump into the filter flask. The mortar was rinsed with acetone, until the liquid became colourless. Lastly, the extract was carried for the optical density measurement. Absorbance was measured at two wavelengths 665 and $649 \mathrm{~nm}$.

Colour measurement. Colour was measured with a spectrophotometer MiniScan XE Plus (Hunter Associates Laboratory Inc., USA). CIEL*a*b* colour parameters were recorded as $\mathrm{L} *$ (lightness), $\mathrm{a} *$ (+ redness) and $b^{*}$ (+yellowness). The chroma $\left(\mathrm{C}^{*}=\left(\mathrm{a}^{* 2}+\mathrm{b}^{* 2}\right)^{1 / 2}\right)$ and hue angle $\left(\mathrm{h}^{\circ}=\arctan \left(\mathrm{b}^{*} / \mathrm{a}^{*}\right)\right)$ were also calculated (McGuiere, 1992).

Statistical analysis. The analyses of chemical composition were carried out in triplicate and colour measurements were carried out in five replicates. The results were statistically processed using MS Excel and software package SELEKCIJA (Tarakanovas, Raudonius, 2003) and are presented as the average of three measurements with the standard errors of the mean. Data of chemical compounds on fresh peppermint was evaluated statistically using one-way, colour characteristics on dry peppermint using two-way and factorial ANOVA analysis. Fisher's LSD test and the determination coefficient were calculated at a probability level of $P \leq 0.05$.

\section{Results and discussion}

The chemical composition of fresh peppermint leaves was determined after harvesting. The results of analyses are presented in Table 1. The amount of dry soluble solids, ascorbic acid, nitrates and carotenoids was similar in both investigated peppermint cultivars or slightly differed. However, the amount of total sugar and chlorophyll substantially differed $(P \leq 0.05)$. Between the examined peppermint cultivars, 'Krasnodarskaja' was characterized by a significantly higher content of total sugar, while 'Peppermint' was characterized by slightly higher total chlorophyll (Table 1). The content of total chlorophyll, ascorbic acid and dry soluble solids observed in the study was similar to that reported by Grzeszczuk and Jadczak (2009).

Essential oil content in the species Mentha piperita (L.) determined by other authors also varied. Adaszyńska et al. (2013) determined peppermint oil in 
Table 1. The quantitative chemical composition of fresh peppermint leaves

\begin{tabular}{|c|c|c|c|c|c|c|}
\hline Fresh leaves & $\begin{array}{c}\text { Total sugar } \\
\%\end{array}$ & $\begin{array}{l}\text { Dry soluble } \\
\text { solids \% }\end{array}$ & $\begin{array}{l}\text { Ascorbic acid } \\
\text { mg } 100 \mathrm{~g}^{-1}\end{array}$ & $\begin{array}{l}\text { Carotenoids } \\
\mathrm{mg} 100 \mathrm{~g}^{-1}\end{array}$ & $\begin{array}{l}\text { Chlorophyll } \\
\text { mg } 100 \mathrm{~g}^{-1}\end{array}$ & $\begin{array}{l}\text { Nitrates } \\
\text { mg } 100 \mathrm{~g}^{-1}\end{array}$ \\
\hline 'Peppermint' & 2.06 & 10.6 & 22.43 & 5.7 & $169.0^{*}$ & 83.0 \\
\hline 'Krasnodarskaja' & $2.26^{*}$ & 10.6 & 21.53 & 5.8 & 139.0 & 82.8 \\
\hline $\mathrm{LSD}_{05}$ & 0.029 & 0.069 & 1.185 & 0.143 & 1.50 & 2.364 \\
\hline
\end{tabular}

Note. * - values are significantly different $(P \leq 0.05)$ by Fisher's LSD test.

the tested peppermint 'Asia' at the level of $2.1 \%$. The highest content $(0.77 \%)$ of essential oil was determined in the fresh leaves of the cv. 'Peppermint'. In the leaves of cv. 'Krasnodarskaja', essential oil accounted for $0.70 \%$ of fresh mass. The results obtained in this study are comparable to those determined by other researchers. The mint leaves from conventional farming have mint oil content at the level $0.75-1.89 \%$ (Newerli-Guz, Kobylańska, 2013). The results of essential oil content in the dried herbs are given in Figure 1. The drying method affected the essential oil content of dried peppermint leaves. However, the changes between the investigated peppermint cultivars were different. Larger quantities of essential oil in dry mass remained in both types of peppermint leaves, which had been dried by active ventilation, vacuum, convection and sublimation. The lowest essential oil content remained when leaves were dried with high-frequency waves $-0.08 \%$ d.m. (cv. 'Krasnodarskaja') and $0.065 \%$ d.m. (cv. 'Peppermint'). This confirms previously obtained findings suggesting that drying with high-frequency waves, in other plants, for example, melissa (Melissa officinalis L.), significantly reduced essential oil (Dambrauskienè, Viškelis, 2002). Among the variously dried peppermint plants, cv. 'Krasnodarskaja' had higher oil volumes (0.64-0.68\%) mostly when dried by active ventilation at $20 \pm 2.0^{\circ} \mathrm{C}$ temperature (Fig. 1). In dried cv. 'Peppermint', the essential oil content remained lesser, depending on the drying method $-0.48 \%\left(30 \pm 2.0^{\circ} \mathrm{C}\right.$ under vacuum $)$ and $0.62 \%$ d.m. $\left(20 \pm 2.0^{\circ} \mathrm{C}\right.$ dried by active ventilation $)$. Comparison of the results showed that different drying methods used had a significant effect on essential oil

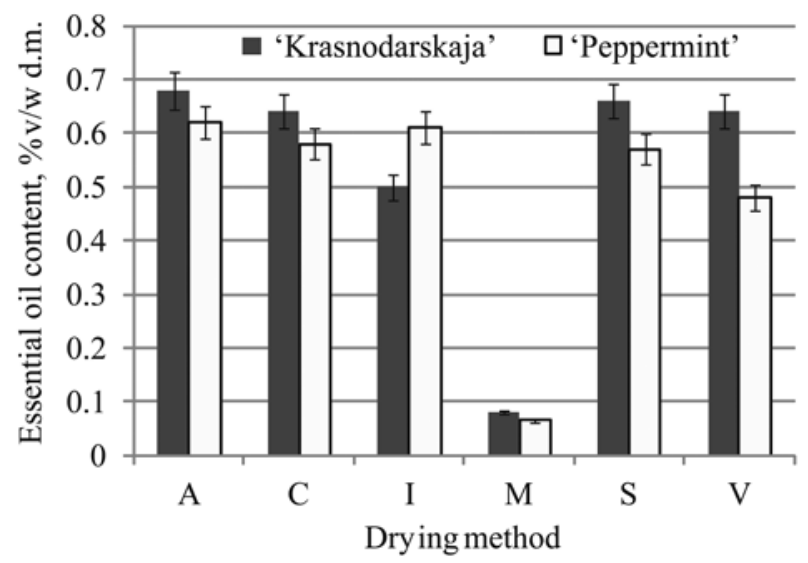

A - active ventilation, $\mathrm{C}$ - convection, I - infrared, $\mathrm{M}$ microwave, $\mathrm{S}$ - sublimation, $\mathrm{V}$ - vacuum; d.m. - dry mass

Figure 1. The essential oil content in dried peppermint leaves percentages. These results are in agreement with those obtained by other researchers (Papageorgiou et al., 2008). They observed that oven-drying at $45^{\circ} \mathrm{C}$ and air-drying at ambient temperature are the methods that produced the best results. Freeze-drying resulted in substantial losses in oxygenated aromatic compounds (Díaz-Maroto et al., 2003).

Chlorophyll is a group of compounds responsible for colour (such as green) intensity of plants. In the case of degradation, there is also the deterioration of colour, flavour and nutritional value. The results show that drying has a significant impact on chlorophyll degradation; however, the level of its losses is different for each herb species (Śledź, Witrowa-Rajchert, 2012). Plant properties and drying methods had influence on the stability of chlorophyll $a$ and $b$ in peppermint leaves. Larger quantities of pigments remained in dried leaves of the cv. 'Peppermint' - 302.0-715.0 mg $100 \mathrm{~g}^{-1}$ - and most of them are found in sublimation/lyophilisation dried leaves (Fig. 2). Chemical composition of chlorophyll $a$ and $b$ is very similar, but they differ in colour. Chlorophyll $a$ is bluish-green, chlorophyll $b-$ yellow-green. Chlorophyll $a$ is more widespread and important, because without it there is no photosynthesis. Plants have less chlorophyll $b$ than chlorophyll $a$, and the latter varies more in mints (Grzeszczuk, Jadczak, 2009). As noted before, the stability of chlorophyll $a$ and $b$ in peppermint leaves depends on drying methods. Depending on the drying method, greater chlorophyll differences between peppermints were in sublimation dried leaves. In the peppermint cultivar from Poland, chlorophyll $a$ amount was $419.0 \mathrm{mg} 100 \mathrm{~g} \mathrm{~g}^{-1}$, while cv. 'Krasnodarskaja' leaves had twice as low amount -189.0 $\mathrm{mg} 100 \mathrm{~g}^{-1}$. The results of chlorophyll $b$ amount also differ - in the leaves of Polish peppermint there was 2.3 times more chlorophyll $b$ than in those of cv. 'Krasnodarskaja'. When peppermint cultivar from Poland was dried by other methods, chlorophyll $a$ averaged $238.0 \mathrm{mg} 100 \mathrm{~g}^{-1}$, chlorophyll $b-164.0 \mathrm{mg} 100 \mathrm{~g}^{-1}$. Meanwhile in dried leaves of cv. 'Krasnodarskaja' chlorophyll $a$ averaged $172.0 \mathrm{mg} 100 \mathrm{~g}^{-1}$, chlorophyll $b-117.0 \mathrm{mg} 100 \mathrm{~g}^{-1}$.

The ratio between chlorophyll $a$ molecules and chlorophyll $b$ molecule is 3:1 (Grzeszczuk, Jadczak, 2009), sometimes this ratio can be greater. In investigated fresh peppermint leaves, chlorophyll $a$ and $b$ ratio was 1.44 (cv. 'Krasnodarskaja') and 1.35 (cv. 'Peppermint'). In dried peppermint, this rate varied in all samples (Fig. 3). The greatest chlorophyll $a$ to $b$ ratio (1.57) was found in cv. 'Krasnodarskaja' leaves that were dried in vacuum at $30 \pm 1.0^{\circ} \mathrm{C}$ temperature. In comparison with fresh leaves, in dried leaves of cv. 'Krasnodarskaja' chlorophyll $a$ and $b$ ratio was approximately $2.6 \%$ 


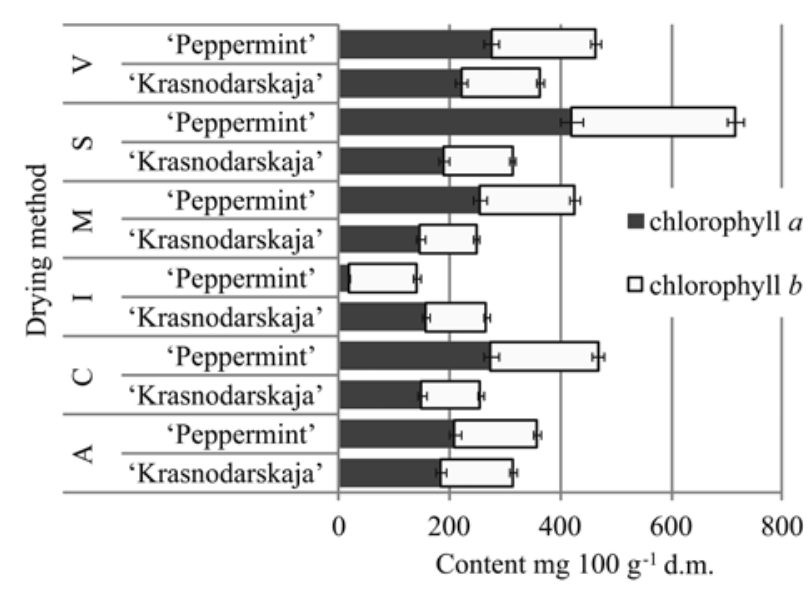

A - active ventilation, C - convection, I - infrared, $\mathrm{M}$ microwave, $\mathrm{S}$ - sublimation, $\mathrm{V}$ - vacuum; d.m. - dry mass

Figure 2. Content of chlorophyll $a$, chlorophyll $b$ and total $(a+b)$ chlorophyll in peppermint leaves as influenced by the drying method

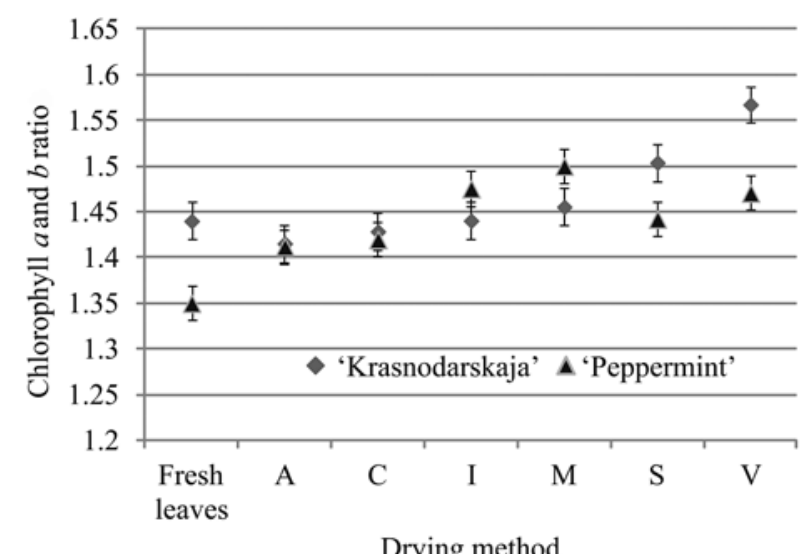

A - active ventilation, C - convection, I - infrared, M microwave, $\mathrm{S}$ - sublimation, $\mathrm{V}$ - vacuum

Figure 3. Drying method influence on chlorophyll $a$ to $b$ ratio in peppermint leaves smaller. However, dried leaves of cv. 'Peppermint' had higher changes in chlorophyll $a$ and $b$. That was seen by the ratio changes in both chlorophylls, the ratio changed from 1.41 to 1.50 and in comparison with fresh leaves, depending on drying method, it varied from $4.6 \%$ (active ventilation) to $11.1 \%$ (microwave). Similar chlorophyll $a$ and $b$ differences were in both investigated peppermint cultivars, which were dried naturally $\left(20 \pm 2.0^{\circ} \mathrm{C}\right)$ and by convection $\left(40 \pm 2.0^{\circ} \mathrm{C}\right)$. Higher changes between ratios were in sublimated peppermint leaves (Fig. 3).

Results from colour analysis of fresh and dried material are presented in Table 2. The dried cv. 'Peppermint' leaves, in which chlorophyll retention was the highest, were characterised by the greatest colour stability. Fresh and dried leaves of cv. 'Peppermint' had the lowest brightness $L^{*}$ value (from 22.61 to $35.24)$, particularly when dried in sublimation, and were significantly $(P \leq 0.05)$ different from the dried $\mathrm{cv}$. 'Krasnodarskaja' samples (Table 2). Dried samples of cv. 'Krasnodarskaja' peppermint had the lowest brightness L* value of 31.97, when leaves were dried using convection method. It was found that lightness was not significantly affected by the drying method (Krokida, Maroulis, 1999). The change of green colour was largely related to the loss of chlorophyll. It was found that greater retention of chlorophyll $a$ was accompanied by lesser change of green colour in the direction of red (Śledź, Witrowa-Rajchert, 2012). The biggest changes in greenness $a^{*}$ value were in both peppermint samples, that had been dried by microwave $(P \leq 0.05)$. The positive value of greenness $\mathrm{a}^{*}$ in the cv. 'Peppermint' (1.92) shows that the samples dried by a microwave had a reddish tint.

The yellowness $b^{*}$ values differed for dried and fresh samples. Active ventilation, vacuum and sublimation dried samples were statistically different from convective, infrared and microwave dried samples. Other authors also obtained similar results of colour changes for peppermint (Arslan et al., 2010). Fresh and dried leaves of the cv. 'Peppermint' had the lowest yellowness $\mathrm{b}^{*}$ values (from 9.35 to 17.00 ) and were significantly

Table 2. The influence of different drying methods on peppermint colour characteristics

\begin{tabular}{|c|c|c|c|c|c|c|}
\hline \multirow[b]{2}{*}{ Drying method } & \multirow[b]{2}{*}{ Peppermint leaves } & \multicolumn{5}{|c|}{ Colour characteristics } \\
\hline & & $\begin{array}{c}\text { lightness } \\
\mathrm{L}^{*} \\
\end{array}$ & $\begin{array}{c}\text { red/green } \\
\mathrm{a}^{*} \\
\end{array}$ & $\begin{array}{c}\text { yellow/blue } \\
\mathrm{b}^{*}\end{array}$ & $\begin{array}{c}\text { chroma } \\
\mathrm{C}^{*}\end{array}$ & $\begin{array}{c}\text { hue angle } \\
\mathrm{h}^{\circ}\end{array}$ \\
\hline \multirow{2}{*}{ Fresh leaves } & 'Krasnodarskaja' & $35.98 \pm 1.75$ & $-7.92 \pm 0.77$ & $15.54 \pm 3.14$ & $17.47 \pm 3.01$ & $117.4 \pm 3.99$ \\
\hline & 'Peppermint' & $31.02 \pm 2.41$ & $-5.96 \pm 0.58$ & $9.35 \pm 0.57$ & $11.09 \pm 0.77$ & $122.5 \pm 1.35$ \\
\hline \multirow{2}{*}{ Active ventilation (A) } & 'Krasnodarskaja' & $40.60 \pm 4.54$ & $-4.29 \pm 2.94$ & $19.84 \pm 4.61$ & $20.40 \pm 4.68$ & $100.8 \pm 7.57$ \\
\hline & 'Peppermint' & $33.41 \pm 3.18$ & $-3.78 \pm 1.10$ & $14.32 \pm 1.82$ & $14.83 \pm 2.02$ & $104.6 \pm 2.61$ \\
\hline \multirow{2}{*}{ Convection (C) } & 'Krasnodarskaja' & $31.97 \pm 0.96$ & $-0.22 \pm 1.59$ & $12.97 \pm 2.36$ & $13.04 \pm 2.42$ & $90.35 \pm 6.44$ \\
\hline & 'Peppermint' & $29.53 \pm 3.38$ & $-1.23 \pm 0.26$ & $11.20 \pm 0.99$ & $11.27 \pm 0.99$ & $96.3 \pm 1.39$ \\
\hline \multirow{2}{*}{ Infrared (I) } & 'Krasnodarskaja' & $34.34 \pm 1.23$ & $-2.76 \pm 2.49$ & $15.30 \pm 2.81$ & $15.66 \pm 3.14$ & $98.99 \pm 7.97$ \\
\hline & 'Peppermint' & $31.89 \pm 1.92$ & $-0.67 \pm 1.28$ & $13.50 \pm 1.88$ & $13.55 \pm 1.96$ & $92.43 \pm 4.66$ \\
\hline \multirow{2}{*}{ Microwave (M) } & 'Krasnodarskaja' & $37.90 \pm 5.77$ & $-1.64 \pm 1.24$ & $17.42 \pm 2.25$ & $17.52 \pm 2.31$ & $95.23 \pm 3.57$ \\
\hline & 'Peppermint' & $22.61 \pm 4.78$ & $1.92 \pm 1.44$ & $10.78 \pm 3.76$ & $11.09 \pm 3.52$ & $77.42 \pm 10.0$ \\
\hline \multirow{2}{*}{ Sublimation (S) } & 'Krasnodarskaja' & $39.80 \pm 5.31$ & $-6.41 \pm 0.94$ & $18.08 \pm 1.14$ & $19.19 \pm 1.37$ & $109.4 \pm 1.63$ \\
\hline & 'Peppermint' & $35.24 \pm 2.65$ & $-5.94 \pm 0.73$ & $17.0 \pm 1.28$ & $18.02 \pm 1.30$ & $109.3 \pm 2.24$ \\
\hline \multirow{2}{*}{ Vacuum (V) } & 'Krasnodarskaja' & $38.76 \pm 2.77$ & $-7.73 \pm 0.41$ & $21.86 \pm 3.48$ & $23.20 \pm 3.38$ & $109.8 \pm 2.32$ \\
\hline & 'Peppermint' & $35.02 \pm 3.15$ & $-5.85 \pm 0.61$ & $15.99 \pm 1.56$ & $17.03 \pm 1.63$ & $110.1 \pm 1.35$ \\
\hline
\end{tabular}

Note. Means \pm SD are given in the Table; significantly $(P<0.05)$ outstanding parameters are shown in bold. 
$(P \leq 0.05)$ different from those of the cv. 'Krasnodarskaja' (Table 2). Convective dried samples had the lowest yellowness $b^{*}$ value changes as compared with fresh peppermint samples. Significantly biggest yellowness $b^{*}$ and chroma $C^{*}$ value changes were observed in sublimation and vacuum dried samples. Chroma values of the microwave dried peppermint leaves did not decrease. In turn, good retention of colour also was observed in nettle (Alibas, 2010) and coriander (Sarimeseli, 2011). The colour saturation or chroma $\left(\mathrm{C}^{*}\right)$ parameter permits the determination of the strength of response to the hue of a colour in a qualitative manner, through interpretation of its intensity and depth (Gozdecka, 2006). Among dried and fresh peppermint, higher chroma $C^{*}$ values were in cv. 'Krasnodarskaja' samples. Between both investigated fresh peppermint plant samples hue angle $\mathrm{h}^{\circ}$ did not differ significantly, but drying method had an impact on the change. In comparison with fresh leaves, significantly large hue angle $\left(\mathrm{h}^{\circ}\right)$ changes were in infrared, convective and microwave dried samples, mostly in the cv. 'Peppermint' leaves.

\section{Conclusions}

1. The investigated fresh leaves of peppermint (Mentha $\times$ piperita L.) plants mostly differed by the amount of total sugar, chlorophyll and essential oil.

2. Among the tested plants, the highest essential oil retention was in variously dried cv. 'Krasnodarskaja' peppermint leaves. Larger amount of pigments remained in the dried leaves of the cv. 'Peppermint', but it had bigger chlorophyll $a$ to $b$ ratio changes.

3. More essential oil remained in the leaves of both peppermint cultivars, which had been dried by active ventilation at a temperature of $22 \pm 2{ }^{\circ} \mathrm{C}$, in vacuum $\left(30 \pm 2^{\circ} \mathrm{C}\right)$, in convective dryer $\left(40 \pm 2^{\circ} \mathrm{C}\right)$ and by sublimation/lyophilisation $\left(-85^{\circ} \mathrm{C}\right)$. Dried by sublimation/lyophilisation and in vacuum leaves of the cvs. 'Peppermint' and 'Krasnodarskaja' had higher chlorophyll content.

4. The changes of colour characteristics of dried leaves dependeded on peppermint properties and drying techniques. The results show that dried leaves of the $\mathrm{cv}$. 'Peppermint' had the lowest brightness $L^{*}$ value and the lowest yellowness $b^{*}$ values. The smallest change in colour characteristics was observed in sublimation and vacuum dried leaves in the investigated cultivars.

5. The microwave drying method ensured retention of chlorophyll and colour, but in dry peppermint leaves left a minimum content of essential oil. Minimum essential oil content, chlorophyll $a$ and $b$ content, and the smallest change in colour were observed in peppermint leaves that had been dried by sublimation, convection and vacuum.

\section{Acknowledgements}

This work was supported by the grant VP1-3.1ŠMM-10-V-02-021, Ministry of Education and Science, European Social Fund Agency, Lithuania.

Received 04082014

Accepted 28032015

\section{References}

Adaszyńska M., Swarewicz M., Markowska-Szczupak A., Jadczak D. 2013. Chemical composition and antimicrobial properties of essential oil and extract from 'Asia' peppermint cultivar. Żywność, Nauka, Technologia, Jakość, 2 (87): 116-125 (in Polish)

Alibas I. 2010. Determination of drying parameters, ascorbic acid contents and color characteristics of nettle leaves during microwave, air- and combined microwave-airdrying. Journal of Food Process Engineering. 33: 213-233 http://dx.doi.org/10.1111/j.1745-4530.2008.00268.x

Antal T., Figiel A., Kerekes B., Sikolya L. 2011. Effect of drying methods on the quality of the essential oil of spearmint leaves (Mentha spicata L.). Drying Technology: an International Journal. 29 (15): 1836-1844 http://dx.doi.org/10.1080/07373937.2011.606519

AOAC. 1990 (a). Vitamin C (ascorbic acid) in vitamin preparations and juice. Official methods of analysis $\left(15^{\text {th }}\right.$ ed.). AOAC International, p. 1058

AOAC. 1990 (b). Sucrose in fruits and fruit products. Official methods of analysis ( $15^{\text {th }}$ ed.). AOAC International, p. 922

AOAC. 1990 (c). Volatile oil in spices. Official methods of analysis $\left(15^{\text {th }}\right.$ ed.). AOAC International, p. 1001

Arslan D., Ozcan M. M., Menges H. O. 2010. Evaluation of drying methods with respect to drying parameters, some nutritionaland colour characteristics of peppermint (Mentha $\times$ piperita L.). Energy Conversion and Management, 51:2769-2775 http://dx.doi.org/10.1016/j.enconman.2010.06.013

Díaz-Maroto M. C., Pérez-Coello M. S., González Viñas M. A., Cabezudo M. D. 2003. Influence of drying on the flavor quality of spearmint (Mentha spicata L.). Journal of Agricultural and Food Chemistry, 51 (5): 1265-1269 http://dx.doi.org/10.1021/jf0208051

Dambrauskienė E., Viškelis P. 2002. Quality of balm (Melissa officinalis L.) dried by different methods. Sodininkystè ir daržininkystè, 21 (4): 86-94 (in Lithuanian)

Edris A. E., Shalaby A. S., Fadel M. A., Wahab A. 2003. Evaluation of a chemo type of spearmint (Mentha spicata L.) grown in Siwa Oasis, Egypt. European Food Research and Technologv. 218: 74-78 http://dx.doi.org/10.1007/s00217-003-0802-4

Gozdecka G. 2006. Application of an objective colorimetric method for the estimation of the colour of meat. Postępy Techniki Przetwórstwa Spożywczego, 16/29 (2): 35-37 (in Polish)

Grzeszczuk M., Jadczak D. 2009. Estimation of biological value of some species of mint (Mentha L.). Herba Polonica, 55 (3): 193-199

Harbourne N., Marete E., Jacquier J.C., O'Riordan D. 2009. Effect of drying methods on the phenolic constituents of meadowsweet (Filipendula ulmaria) and willow (Salix alba). LWT-Food Science and Technology. 42: 1468-1473 http://dx.doi.org/10.1016/j.lwt.2009.05.005

Karaaslan S., Erdem T., Oztekin S. 2013. Mathematical modelling and color characteristics of purslane (Portulaca oleraceae L.) leaves using different drying methods. Philipp Agriculture Scientist, 96 (3): 267-274

Kavak Akpinar E. 2006. Mathematical modeling of thin layer drying process under open sun of some aromatic plants. Journal of Food Engineering, 77 (4): 864-870

Kizil S., Haşimi N., Tolan V., Kilinç E., Yüksel U. 2010. Mineral content, essential oil components and biological activity of two mentha species (M. piperita L., M. spicata L.). Turkish Journal of Field Crops, 15 (2): 148-153

Kouhila M., Belghit A., Daguenet M. 2001. Experimental determination of the sorption isotherms of mint (Mentha viridis), sage (Salvia officinalis) and verbena (Lippia citriodora). Journal of Food Engineering, 47 (4): 281-287

Krokida M. K., Maroulis Z. B. 1999. Effect of microwave drying on some quality properties of dehydrated products. Drying Technology: an International Journal. 17 (3): 449-466 http://dx.doi.org/10.1080/07373939908917545 
McGuiere R. G. 1992. Reporting of objective color measurements. HortScience, 27 (12), p. 1254-1255

Mekonnen S. A. 2011. Agronomic characters. Leaf and essential oil yield of peppermint (Mentha piperiata L.) as influenced by harvesting age and row spacing. Medicinal and Aromatic Plants Science and Biotechnology, 5 (1): 49-53

Newerli-Guz J., Kobylańska A. 2013. Quality evaluation of herbal teas - on the example of Mentha piperita. Problemy Higieny i Epidemiologii, 94 (4): 862-865 (in Polish)

Orphanides A., Goulas V., Gekas V. 2013. Effect of drying method on the phenolic content and antioxidant capacity of spearmint. Czech Journal of Food Sciences, 31 (5): 509-513

Padmini E., Valarmathi A., Usha Rani M. 2010. Comparative analysis of chemical composition and antibacterial activities of Mentha spicata and Camellia sinensis. Asian Journal of Experimental Biological Sciences, 1 (4): 772-781

Papageorgiou V., Mallouchos A., Komaitis M. 2008. Investigation of the antioxidant behavior of air- and freezedried aromatic plant materials in relation to their phenolic content and vegetative cycle. Journal of Agricultural and Food Chemistry. 56 (14): 5743-5752 http://dx.doi.org/10.1021/jf8009393

Risch S. J. 1997. Spices: sources, processing, and chemistry. Risch S. J., Ho C. T. (eds). Spices flavour chemistry and antioxidant properties. American Chemical Society, p. 2-6

Rocha R. P., Melo E. C., Radünz L. L. 2011. Influence of drying process on the quality of medicinal plants: a review. Journal of Medicinal Plants Research, 5 (33): 7076-7084

Sarimeseli A. 2011. Microwave drying characteristics of coriander (Coriandrum sativum L.) leaves. Energy Conversion and Management. 52: 1449-1453 http://dx.doi.org/10.1016/j.enconman.2010.10.007
Shaw M., Meda V., Tabil L. Jr., Opoku A. 2007. Drying and color characteristics of coriander foliage using convective thin layer and microwave drying. Journal of Microwave Power and Electromagnetic Energy, 41 (2): 56-65

Śledź M., Witrowa-Rajchert D. 2012. Influence of microwaweconvective drying on chlorophyll content and colour of herbs. Acta Agrophysica, 19 (4): 865-876

Stanisavljevic D. M., Stojičevic S. S., Dordevic S. M., Zlatkovic B. P., Veličkovic D. T., Karabegovic I. T., Lazic M. L. 2012. Antioxidant activity, the content of total phenols and flavonoids in the ethanol extracts of Mentha longifolia (L.) Hudson dried by the use of different techniques. Chemical Industry and Chemical Engineering Ouarterly. 18 (3): 411-420 http://dx.doi.org/10.2298/CICEQ110919017S

Sulieman A. M. E., Abdelrahman S. E., Abdel Rahim A. M. 2011. Phytochemical analysis of local spearmint (Mentha spicata) leaves and detection of the antimicrobial activity of its oil. Journal of Microbiology Research, 1 (1): 1-4

Tarakanovas P., Raudonius S. 2003. Agronominiu tyrimy statistinè analizè taikant kompiuterines programas $A N O V A$, STAT, SPLIT-PLOT iš paketo SELEKCIJA ir IRRISTAT, Lithuanian University of Agriculture, 58 p. (in Lithuanian)

Yadegari M., Amirfakhriyan Z., Mohammadkhani A. 2013. The effects of different drying methods on essential oil content and composition and marketing of Lippia citriodora Kunth. Journal of Applied Science and Agriculture, 8 (5): 624-628

Vernon L. P. 1960. Spectrophotometric determination of chlorophylls and pheophytins in plant extracts. Analytical Chemistry. 32: 1144-1150 http://dx.doi.org/10.1021/ac60165a029

\title{
Džiovinimo būdų įtaka pipirmètès (Mentha $\times$ piperita L.) lapų cheminei sudèčiai ir spalvai
}

\author{
M. Rubinskienė, P. Viškelis, E. Dambrauskienė, J. Viškelis, R. Karklelienė \\ Lietuvos agrarinių ir miškų mokslų centro Sodininkystès ir daržininkystės institutas
}

\section{Santrauka}

Tirtos dvi pipirmetès veislès: 'Krasnodarskaja' ir 'Peppermint'. Pipirmètès (Mentha $\times$ piperita L.) augalai buvo džiovinti ịvairiais būdais. Džiovintų ir šviežių pipirméčių tyrimai atlikti taikant biochemijos ir technologijos metodus. Eteriniai aliejai išgauti naudojant garų distiliaciją, chlorofilas $a$ ir $b$ nustatytas spektrofotometriškai pagal Vernon metodiką. Nustatyta, jog daugiausia eterinių aliejų $(0,77 \%)$ ir chlorofilu $\left(169,0 \mathrm{mg} 100 \mathrm{~g}^{-1}\right)$ turèjo veislès 'Peppermint' pipirmètès. Chlorofilų $a$ ir $b$ santykis buvo nevienodas šviežiuose augalų lapuose ir siekè 1,35 veislès 'Peppermint' bei 1,44 veislès 'Krasnodarskaja' pipirmètėse. Pipirméčių lapai džiovinti taikant aktyviają ventiliaciją, konvekcinị, infraraudonųjų spindulių, vakuuminị, mikrobangų ir sublimacinị džiovinimo būdus. Džiovintų augalŭ kokybė priklausė ir nuo augalo savybių, ir nuo džiovinimo būdo. Didžiausias kiekis $(0,64-0,68 \%$ sausos masès) eteriniu aliejų nustatytas ivvairiai džiovinant veislès 'Krasnodarskaja' pipirméčių lapus. Mažiausias kiekis $(0,08$ ir $0,065 \%$ sausos masès) eterinių aliejų nustatytas augalus džiovinant mikrobangomis. Didžiausias kiekis $(715,0 \mathrm{mg}$ $100 \mathrm{~g}^{-1}$ sausos masès) chlorofilu buvo sublimuotuose veislès 'Peppermint' lapuose. Nepaisant džiovinimo būdo, didžiausi chlorofilų $a$ ir $b$ santykio skirtumai nustatyti džiovintuose veislès 'Krasnodarskaja' pipirméčių lapuose. Švieži ir išdžiovinti veislès 'Peppermint' pipirméčių bandiniai turèjo mažiausias šviesumo L* $(22,61-35,24)$ ir geltonumo $b^{*}(9,35-17,00)$ reikšmes. Esminiai koordinatès a* pokyčiai nustatyti džiovintuose mikrobangomis pipirméčių lapuose .

Reikšminiai žodžiai: chlorofilas $a$, chlorofilas $b$, džiovinimo būdai, eterinis aliejus, pipirmètè. 